\title{
Issues related to animal blood into food products: a review paper
}

\author{
${ }^{1}$ Siti Jamilah M.S., ${ }^{1, *}$ Nurrulhidayah, A.F., ${ }^{1}$ Azura., A., ${ }^{2}$ Mat Jubri, S.M., ${ }^{3}$ Abdul Rohman., \\ ${ }^{1}$ Nur Azira, T., ${ }^{4}$ Arieff Salleh, R. and ${ }^{1,5}$ Rashidi, O. \\ ${ }^{1}$ International Institute for Halal Research and Training (INHART), International Islamic University \\ Malaysia (IIUM), 53100 Jalan Gombak, Selangor, Malaysia \\ ${ }^{2}$ Department of Fiqh and Usul al-Fiqh Kulliyyah of Islamic Revealed Knowledge and Human Sciences, \\ International Islamic University Malaysia, 53100 Jalan Gombak, Selangor, Malaysia \\ ${ }^{3}$ Department of Pharmaceutical Chemistry, Faculty of Pharmacy, Universitas Gadjah Mada, Yogyakarta \\ 155281, Indonesia \\ ${ }^{4}$ Center of Research for Fiqh Science and Technology (CFiRST), Universiti Teknologi Malaysia,81310, \\ UTM Johor Bahru \\ ${ }^{5}$ Department of Landscape Architecture, Kulliyyah of Architecture and Environmental Design, International \\ Islamic University Malaysia, Jalan Gombak, 53100 Kuala Lumpur, Malaysia
}

\section{Article history:}

Received: 15 September 2020

Received in revised form: 6 October 2020

Accepted: 30 November 2020

Available Online: 14 March 2021

\section{Keywords:}

Animal Blood,

Food Products,

Issues

DOI:

https://doi.org/10.26656/fr.2017.5(3).512

\section{Abstract}

The rapid development of science and technology has unveiled a new horizon for the food industry by transforming blood into useful food products. This practice seems in line with the sustainable development goal to be implemented by 2030 to improve the efficiency of resources, reduce wastage and to avoid draining natural resources which can lead to environmental degradation. The practice of transforming blood into various food products possesses the potential to minimize harmful environmental issues resulting from blood disposal into land and water. The aim of this review paper to explore the issues related to animal blood into food products because the use of animal blood derivatives are prohibited according to Islamic perspectives and some of religious practitioners. The researcher relied on library research to accomplish the writing process. Sources such as academic journals, governmental agency portals, research papers, thesis, journal articles and trusted websites were used as references. Therefore, this paper aspires to provide insights to researchers to carry out more research in different scopes of studies particularly on the utilization of blood-derived products which can be a sensitive subject among Muslims and other religious practitioners.

\section{Introduction}

According to the Food and Agriculture Organization of the United Nation (FAO) report, 11479 million pints of blood from the slaughterhouse were going down to the drains without any alternative treatment in 2016 in the USA. Meanwhile, in China, it was estimated at around 150 thousand tons of porcine blood was produced per year (Gandhi, 2017). Zafar (2019) emphasized that public health in developing countries is at risk because no systematic strategy was developed to manage the wastewater from abattoirs, with the blood being the major dissolved pollutants for the municipal sewage system. To avoid escalating this issue, the researchers are currently in endeavor in order to minimize the issue of water pollution stemming from slaughterhouse' bloodwastes through innovation and effective management, until properly handled and treated since such waste poses a potential risk to human and animal health (FrankeWhittle and Insam, 2013).

The planning of a sustainable development goal agenda provides a positive vibe to ensure prosperity and peace for the whole universe this agenda addresses environmental care as an important goal in facing global climate change due to uncontrolled wastage practices into water and land resources. Therefore, the involved policymakers are invited to come out with any possible solutions to minimize environmental pollution through the proper cultivation of natural resources (Griggs et al., 2014). The rapid development of science and technology can transform collected blood from slaughterhouses into useful alternative sources for human consumption 
because the blood is composed of unique nutritional and functional qualities (Ofori and Hsieh 2015). This practice is an excellent effort to minimize the environmental impact and encourage innovation to improve resources' sustainability (Lynch et al., 2017). The disposal of animal blood affects the water and land resources due to the high content of biological oxygen demand (BOD), chemical oxygen demand (COD), and nitrogen content. For example, the blood contains approximately $30 \mathrm{~g}$ per liter of nitrogen. The value of COD for blood is $400 \mathrm{~g}$ per liter, while BOD value is $200 \mathrm{~g}$ per liter.

By virtue of this concern, the European Union (Commission Decision 2006/12/EC) established an environmental legislation to encourage the use of animal blood as an alternative solution to minimize environmental problems (Lynch et al., 2017) as it is one of the major pollutants emerging from slaughterhouses (Zafar, 2019).

Furthermore, the developing rendering industry largely contributes to the high demand of blood towards animal feeding industries in producing high quality sources of proteins enriched by amino acids, which provide good sources of vitamins and essential minerals (Meeker and Hamilton, 2006). The process of rendering is performed through the mediums of dry or wet mechanisms (Om Prakash et al., 2018). The applications of blood- based products are not only useful for animal feeding production, but they are also applicable in food industries that produce food additives such as emulsifiers, stabilizers, clarifiers, nutritional additives, egg albumin substitute and pharmaceuticals as well (Quality Meat Scotland, 2009). Although the application of blood provides a significant contribution towards adding-values industrial commodity to some extent, but numerous biological and religious concerns have surfaced such as transmitting spongiform encephalopathy and blood being a prohibited source of human consumption in Islam (Ofori and Hsieh, 2011). Therefore, this paper highlights the issues related to the transformation of animal blood into blood-derived products while exposing food products that incorporate blood derivatives. It also discusses the issue of utilizing animal plasma as a potential source of alternative food additives in surimi products as there are some food manufacturers tend to use animal plasma as an alternative source of cheap protein in order to maximize the profit and minimize cost production.

\section{Materials and methods}

A descriptive qualitative analysis depending on library research was adopted. It comprised an extensive literature review derived from previous studies, research papers, thesis, journal articles, digital newspapers and reliable websites. This review paper was divided into several subtopics related to the usage of animal blood in a variety of food products. Then, to ensure the flow of this review paper is comprehensible and synchronizes well with the proposed topic, several sub-topics are included. Among the subtopics is the usage of animal blood in food products, which generally discussed the usage of animal blood in food products. The authors also specifically included the issue of animal plasma as a potential source of alternative food additives in surimi products as an example of the study case.

\section{The usage of animal blood in food products}

Collected animal blood from slaughterhouses has a higher risk of contamination by pathogens if used in food manufacturing such as black pudding which is commonly sold at supermarkets and street vendors (Barton, 2000). Failing to inspect hygiene levels and implementing a monitoring system during the blood collection process contributes to the growth of pathogens which mainly occurs when the bleeding starts (Parés et al., 2011). As of late, consumers have risen up concerns to have proper food labels indicating the protein source used that might be extracted from blood-derived ingredients (Ofori and Hsieh, 2017). The need to have proper labelling is crucial because blood- derived products may potentially be affected by zoonotic threats such as hepatitis E virus (HEV) if the blood is not properly sterile or is collected from unhealthy animals (Boxman et al., 2017). The act of recycling animal blood is considered as an alternative solution to minimize environmental problems as a result of unsystematic blood disposal from slaughterhouses. It is estimated that $30 \%$ of food products use animal blood as a main ingredient, mainly in meat-based goods to enhance gelling activities and function as a natural colorant (Bah et al., 2016). This is because blood naturally comprises several compounds that provide a good source of protein (Bah et al., 2016).

The blood can be reprocessed as an added value for some secondary products such as gelatin, keratin extraction, belts, footwear, and some pharmaceutical products (Alao et al., 2017). Although the use of bloodderived products seems unfit for human consumption, but in reality, blood-derived products are recognized as potential ingredients that can be incorporated into edible products. Based on the research conducted by Walter et al. (1993), it was emphasized that the blood hemoglobin is considered as a good source of iron for school children and can be added in snacks such as biscuits. In addition, they claimed that the small quantity of hemoglobin used 
could be a substitute for chocolate colorant. For example, in Kenya, bovine blood is used as a vital source to produce porridge flour as an alternative effort to combat anemia among young children.

This alternative effort was introduced to replace cereal porridge flour that comprised very low iron levels and poor bioavailability (Andago et al., 2015). After realizing the nutritional value of hemoglobin, the process of decolorizing globin from heme pigment is getting more popular to get rid of its dark-brownish color (Yang and Lin, 1998). In addition, the breakdown of hemoglobin can eliminate the metallic flavor which is unfit to be in edible food additives (Duarte et al., 1999). In the same way, the blood of sheep, pigs and cattle can generally be transformed into edible food additives. The deer blood can also provide beneficial nutritive values such as controlling the level of body fat in blood and can supply oxygen to human beings (Bah et al., 2016). Meanwhile, the goat blood also provides a good source of protein, fat and minerals such as iron and phosphorus (Alao et al., 2017). It was during World War 1 that blood became an essential component for approximately $10 \%$ of peoples 'meals to accommodate their dietary needs (Bates et al., 1974).

Plasma is another blood component that is widely used in the food industry. In general, the blood plasma has been transformed into powder to facilitate its addition during the manufacturing process of food products particularly in meat-based goods (Kashim et al., 2015). Similarly, (Ofori, 2006) mentioned several functions of blood plasmas which are; a natural coloring for meat product, gelling, emulsifying; and a binding and coloring agent in blood sausages and cured meat; and enhancing the red color in meat products. The various applications of blood plasma in the food industry gives a depict that the halal-ness status of food is ambiguous especially that the incorporation of blood can be categorized as an impure element in producing food products (Mahaiyadin et al., 2019). Plus, due to consumes' interest and their religious concern, the usage of blood plasma is restricted and is not being fully utilized. This is also due to the belief that it negatively impacts human health based on scientific evidence, which proved that blood contains higher quantities of microbes (Esa et al., 2018).

Blood plasma plays a vital role in the meat industry due to its ability to form a gel once heated. Also, its binding characteristics are claimed to be much better than other binders such as meat powders, gelatin, wheat gluten, isolated soy protein, and a combination of sodium alginate and calcium carbonate, although its binding characteristics are inferior to egg whites ( $\mathrm{Lu}$ and Chen,
1999). However, at acidic $\mathrm{pH}$, plasma produces a soft gel, but it is not effective as a gelling agent specifically in fermented products (Parés et al., 2011). Another functionality of blood plasma is that it can produce a better emulsifying capacity compared to globin, specifically in products such as frankfurter, pate, luncheon meat and mortadella, as plasma helps to bind the meat proteins, fat, and water in a stable form (Silva and Silvestre, 2003)

Moreover, blood plasma can be a substitute for fat so that the right texture can be obtained. In addition, it can be a fat alternative in some diets which provides a source of vitamins, essential fatty acids and energy, since the consumption of fat is also not good for the consumer's health due to the high content of saturated fatty acids that can lead to serious health problems (Mela, 1990). Although the meat industry remains the predominant user of blood proteins, other sectors of the food industry, specifically the pastry industry, are using this source to stabilize the cake volume and enhance its texture due to its unique capabilities (Colmenero, 1996). Therefore, blood plasma can be an alternative for eggs, which aids in reducing the cost of production and simultaneously reduces the level of cholesterol in baked products (Ashwini, 2009). In a nutshell, the functionality of blood plasma is undeniable, and its applications are numerous, but to preserve the consumer rights and religious concerns it is very important to have an insightful analysis of its halal status according to Shari'ah Perspectives. To have a comprehensive argumentation, halal authenticity detection is very important in order to test the availability of blood plasma in sample products so that the food labeling for these products can be emphasized and implemented in the future.

Pork gelatin is normally added into surimi products to act as a gelling protein together with other substances. But, the addition of gelatin may weaken the structure of surimi textures and lead to lesser elasticity of Surimi Products (Sun and Holley, 2011). To find a better alternative, several proteins supplements have been added into surimi or meatball products such as blood plasma protein, whey protein, soy protein and egg whites (Rawdkuen and Benjakul, 2004).The usage of these proteins is permissible except for plasma protein since some Muslim consumers believe that it is derived from blood and therefore is prohibited for human consumption. According to a study by Aravindran et al. (2014) at Klang Malaysia, industries are using alternative sources such as chicken and goat plasma protein.

To have an overview on the usage of animal-blood derivatives and arising issues, the authors summarized the findings in Table 1 . 
Table 1. Summary of potential blood-derivatives in food products and arising issues

\begin{tabular}{|c|c|c|}
\hline Author & Usage & Arising Issues \\
\hline Barton (2000) & Black Pudding products & $\begin{array}{l}\text { Potentially be affected by zoonotic threats such as hepatitis E } \\
\text { virus (HEV) as a result of improper sterilization and collection } \\
\text { from unhealthy animals (Boxman et al., 2017). }\end{array}$ \\
\hline Alao et al. (2017) & $\begin{array}{l}\text { Added value for gelatin, keratin } \\
\text { extraction, belts, footwear, and } \\
\text { pharmaceuticals products }\end{array}$ & $\begin{array}{l}\text { Polemic claimed that bovine blood can be a potential alternative } \\
\text { iron source to combat anemia among the young children } \\
\text { (Andago et al., 2015). }\end{array}$ \\
\hline Walter et al. (1993) & $\begin{array}{l}\text { Alternative iron source for } \\
\text { schoolchildren snacks }\end{array}$ & $\begin{array}{l}\text { Increase the process of decolorizing globin from heme pigment } \\
\text { to improve the nutritive value of blood's hemoglobin } \\
\text { (Yang and Lin, 1998). }\end{array}$ \\
\hline Andago et al. (2015) & Porridge flour & Leaves metallic taste in food products (Duarte et al., 1999). \\
\hline Bates et al. (1974) & $\begin{array}{l}\text { Added additive in meals during the } \\
\text { First World War } 1\end{array}$ & $\begin{array}{l}\text { Potential good protein source, fat, minerals, phosphorus } \\
\text { and iron (Alao et al., 2017). }\end{array}$ \\
\hline Ofori and Hsieh (2012) & $\begin{array}{l}\text { Binder agent for Meat }- \text { Based } \\
\text { products }\end{array}$ & $\begin{array}{l}\text { Halalness status of products might be in doubtful } \\
\text { status (Mahaiyadin et al., 2019). }\end{array}$ \\
\hline Silva and Silvestre (2003) & Emulsifier in meat-based products & $\begin{array}{l}\text { Food safety is not guaranteed as the blood composed with higher } \\
\text { microbial quantity (Esa et al., 2018). }\end{array}$ \\
\hline Mela (1990) & $\begin{array}{l}\text { Potential fat alternative in dietary } \\
\text { products }\end{array}$ & $\begin{array}{l}\text { Demand for halal authentication detection to detect the presence } \\
\text { of blood derivatives in food products (Sun and Holley, 2011; } \\
\text { Aravindran et al., 2014; Rawdkuen and Benjakul, 2004). }\end{array}$ \\
\hline Colmenero (1996) & Stabilize the cake volume and texture & \multirow{3}{*}{$\begin{array}{l}\text {-Demand for proper labelling in food products to preserve the } \\
\text {-consumer's interest from food fraud issue (Sahilah et al., 2016). }\end{array}$} \\
\hline Ashwini (2009) & Egg's replacer & \\
\hline Ofori and Hsieh (2012) & Natural Colorants & \\
\hline
\end{tabular}

\section{The development of surimi products}

The term surimi is derived from the Japanese term to represent the uniqueness of its process which comprises several steps such as heading, gutting, filleting, deboning (mincing), washing, dewatering, refining, mixing with cryoprotectants, freezing, and metal detection for Halal Critical Control Point (HACCP) (Ramírez et al., 1999). The shapes, patterns and ingredients used in making surimi products represent the culture of a certain nation which can be recognized through the physical appearance of surimi shapes (Mansfield, 2003). Surimi products originally belong to traditional Japanese cuisine, whereby the earliest processing procedure of surimi was noted in a Japanese cookbook in 1528. Currently, around $2-3$ percent of the world fisheries contribute towards surimi production whether for surimi or surimi- based products that involve more complex procedures (Vidal-giraud and Chateau, 2007).

The idea of preparing surimi from minced fish meat was originated from Japan due to the unavailability of refrigerators or fridges to maintain the freshness of fish for a longer period. Initially, the preparation of surimi using simple techniques such as removing the flesh, smashing the flesh with a grinder, removing the water, mixing the sugar and condiments and adding salt as the enhancer of gelling activities till a fish gel called 'kamaboko' is formed. Over time, the manufacturing industry has witnessed the advancement of Kamaboko preparation from a simple recipe to a variety of commercialized kamaboko products such as chikuwa, satsumage, analogues ham and kamaboko sausage (Pigott 2009). It is stated that Japanese customers are loyal and appreciative towards the Japanese market of surimi and will not trust the American surimi production (Satam and Yusufzai, 2002). United States was recognized as among the biggest surimi consumers instead of other Southeast Asian countries such as Thailand, Vietnam and Malaysia (Ministry of Agriculture Malaysia, 2010) due to the unique textural properties and high nutritional values that surimi adds into the products (Santana et al., 2012). The rising popularity of surimi products around the globe is influenced by the demand from surimi producers to limit the usage of fresh fish, which is quite challenging in terms of handling, transporting, preparing and ensuring the freshness of fish for a longer time. The evolution process of surimi products into other sub-products such as fishballs, fish cakes, nuggets, sausages, crabsticks, artificial scallops and others, made surimi products more favorable, particularly for those suffering from seafood allergies (Jabatan Perikanan Malaysia, 2015).

In the context of Malaysia, there are three main surimi products dominating the Malaysian surimi industry, namely surimi, otoshimi and surimi-based products. Also, with Malaysia possessing an abundance of sources for marine fish ,namely barracuda, lizardfish, threadfin bream big eye, croaker and goatfish, it contributed to the development of the surimi industry not only in Malaysia, but has also expanded to many countries such as Japan and Singapore. However, Malaysia still imports surimi products from U.S.A, Chile 
and several other countries (Siriraksophon et al., 2009). Kok et al. (2013) noted that fish balls are the secondlargest processed fish-based product in Malaysia which accumulates to $15-20 \%$ of fish-based processed food products in Malaysia. In 2016, it was reported by Wahab (2017) that Malaysia's total imports of consumeroriented and edible fishery products achieved a very impressive achievement in accumulating approximately $\$ 7.1$ billion. However, it is also noted that Malaysia still depends on several countries to import fish and seafood products in order to support customers' demand with China being the main supplier ( $\$ 234$ million), followed by Indonesia ( $\$ 171$ million) and Thailand ( $\$ 81$ million).

Upon realizing the potential of fish-based processed products in the market, the Malaysian government encouraged its citizens to invest in small-medium entrepreneurship businesses under the Malaysian Agriculture Research Development Institute (MARDI) training. This gesture can be seen as a positive effort from the government to give exposure on how to handle a business for beginners, give assistance in terms of providing and handling processing -machine and ensure that beginners are keeping up to date with the latest research related to the variety of fish -based food products in the market (Suhana and Omar, 2019). Surimi products are considered one of the most favored fishbased products among Malaysian consumers, although it is challenging to determine the exact consumption rates due to the lack of reliable data. However, the report of Global Agricultural Information Network stated that fish processing including surimi products is a sub-leading sector in Malaysia which contributed to export -values from 2011-2016 followed by noodle manufacturing and meat processing (Wahab, 2017). Yet, the production of surimi in various shapes such as fish balls, fish cakes, nuggets, scallops and kamaboko is capable of minimizing allergic reactions specifically for those who are allergic towards fresh seafood like prawn and crab (Jabatan Perikanan Malaysia, 2015). In Malaysia, QL
Foods Sdn. Bhd is recognized as the largest surimi producer located in Perak State. An average of production is around $82,000 \mathrm{MT}$ per year, as reported by the Fishery Agriculture Marketing Agency (FAMA) (Pangsorn et al., 2007). Some of the popular brands produced by this company are Mushroom, OceanRia, Suria and Ika's in various colors, shapes and sources of raw materials in order to cater to the varying tastes and demands of consumers (QL Foods Sdn. Bhd, 2014). Although this company belongs to a Non-Muslim owner, it has fulfilled Department of Islamic Development Malaysia (JAKIM) requirements to obtain a Halal certificate by adhering to the Hazard Analysis Critical Control Point (HACCP Principles during the handling process till the products are successfully delivered to the customers.

The factors lead to the development of the surimi Industry is summarized in Figure 1.

The selection of the right raw materials is vital to ensure the quality and taste of the end product of surimi. In general, the fish used as a raw material needs to have a lower cost, white meat, non-oily, can produce good gelling activities and is accessible throughout the year to ensure continuous supply (Birla et al., 2018). For example, in the Southeast Asia; Thailand, Malaysia, Indonesia, Vietnam and Myanmar used fish as the main raw material for surimi products from several species such as threadfin bream, big-eye snapper, lizardfish, croaker, goatfish or red mullet, barracuda, sardines and rainbow runner (Elagatis bipinnulata) caught by fishermen in areas such as West Kalimantan, Cat Ba Island, Hai Phong and Bach Long Island (Siriraksophon et al., 2009).

The first step begins with peeling off the fish's skin followed by the deboning process to remove the bones from the fillet (Martín-Sánchez et al., 2009). In addition, conducting the washing process efficiently after selecting the fish types that will be used in the surimi production is

Introduced in Japan as the first stepping- stone leads to the popularity of surimi products worldwide (Vidal-

giraud and Chateau, 2007)

The idea of formulation surimi recipe to limit the usage of fresh fish that need proper handling

(Jabatan Perikanan Malaysia, 2015)

The richness of aquatic fish sources (Siriraksophon et al., 2009)

Comprised with unique textural properties and high nutritional values added into the products (Santana et

al., 2012)

High demands from consumers (Wahab, 2017)

Surimi production provides job opportunity for the startup businessman, particularly those involved in SmallMedium Entrepreneurship (Suhana and Omar, 2019)

The surimi products have been innovated in attractive presentation, colorful and in a variety of shapes (Jabatan Perikanan Malaysia, 2015).

Emergence of the company involved in halal surimi production (QL Foods Sdn. Bhd., 2014).

Figure 1. Factors lead the development of surimi industry 
a crucial factor that can affect the quality of the final product. Jin et al. (2011) reported that the washing process results in the loss of some myofibrillar proteins, myosin, and actin due to repetitive washing. This practice is carried out to ensure that undesirable compounds are totally isolated from minced fish. To minimize the loss of myofibrillar proteins, it was suggested to use a sufficient amount of water in the first step of washing to remove any undesirable compounds found in the minced fish. The washed fish mince will be strained to get a concentrated fish paste before the block of surimi is separated according to grades and dehydrated. To preserve the freshness and quality of surimi blocks, the products are frozen, which is known as the cryoprotectants process. Cryoprotectant is a substance used to stabilize the enzyme activities and add sweetness. It particularly imparts sucrose and sorbitol in surimi dough which contributes to its commercialization in the global market. Conventionally, the ratio of sucrose and sorbitol mixture that is used to formulate cryoprotectant is 1:1 (Tian et al., 2010).

\section{Plasma as a critical ingredient in Halal surimi products}

The progressive development of science and technology creates a new dimension in the food industry. Muslims are particularly being exposed to various questionable ingredients in manufactured foods. Admittedly, consumers are in need of proper labelling and clear data to ensure that they are acquainted with the true nature of ingredients used in the products (Sahilah et al., 2016). It is because science and technology have created new food technologies replacing the traditional methods of manufacturing foods to be more attractive in terms of taste, colour and physical appearance (Aravindran et al., 2014). Due to this concern, a traceability system must be implemented by companies, particularly among halal manufacturers to be in line with the Halal assurance system standard (Rahman and Abdul 2017). Yet, the incorporation of muharramat (prohibited) sources is growing more popular in several food products which can threaten the halal status of these products as noted by (Mahaiyadin et al., 2019).

In general, the ingredients used in surimi production are easily accessible which include minced fish, starch, salt, vegetable oil, soy protein, transglutaminase enzyme, whey protein, food additives such as monosodium glutamate (MSG), sorbitol, sucrose, glucose and polyphosphate to give a balanced sweet taste for the surimi (Anuar, 2015). However, tranglutaminase enzyme and whey protein are listed as questionable ingredients that may be incorporated into surimi products which are derived from non halal sources such as porcine plasma protein (Sahilah et al., 2016). The usage of blood plasma protein is controversial by consent of some contemporary Muslim scholars such as Al- Zuhaily, Abdul Majid, Said Hawwa, Al- Qaradhawi and Waleed Khalid who opined the application of blood plasma is permissible if the process of Istihalah (transformation) was carried out correctly, because reason of prohibition is the flow of the blood that is spilled upon the ground, although the majority of scholars stand with the opinion that the usage of blood plasma must be prohibited in Islam (Mohd Izhar Ariff et al., 2017)

The process of extracting blood plasma is believed to be more sustainable; however, slaughterhouses are simply discarding the collected blood which can lead to serious environmental problems as claimed by Ofori and Hsieh (2011) and Lynch et al. (2017). Commonly, the usage of blood plasma in surimi products is benefecial where it acts as a gelling agent (Parés et al., 2011), binding agent ( $\mathrm{Lu}$ and Chen, 1999) and acts as an emulsifier in surimi processing activities (Silva and Silvestre, 2003). Although blood plasma provides some nutritional values in surimi products, its application in food products may lead to possible health risks as stated by scientific evidence proving that blood contains a higher microbial quantity (Esa et al., 2018) aside from the issue of religious sensitivity (Ofori and Hsieh, 2011). Due to religious concerns, the Halal Certification Bodies in some countries are prohibiting the application of blood plasma in food products. . For example, the Department of Islamic Development Malaysia (JAKIM) forbids its use, although the source of blood plasma is derived from permissible animals since the blood plasma is extracted from blood spilled-out from animals as included in najs category (Anuar, 2015).

The transglutaminase (TGase) enzyme derived from blood plasma acts as a catalyst between protein bonds and affects protein properties, protein gel capacity, thermal stability, water holding capacity which can influence elasticity, mouth feel, flavor, texture and binding force of surimi products (Alina et al., 2013). Due to these characteristics, the blood plasma is considered as a suitable alternative source to produce transglutaminase enzyme, particularly for processed meat products and fish based-processed products such as fish balls and crab -sticks (Ramli et al., 2018). Research conducted by Fowler and Park (2015) confirmed that the protein found in salmon blood plasma can be a good alternative for transglutaminase enzyme despite using mammalian sources because they inhibit the protease enzyme that can enhance surimi gelation.

The functions of animal plasma in surimi products are summarized in Figure 2. 


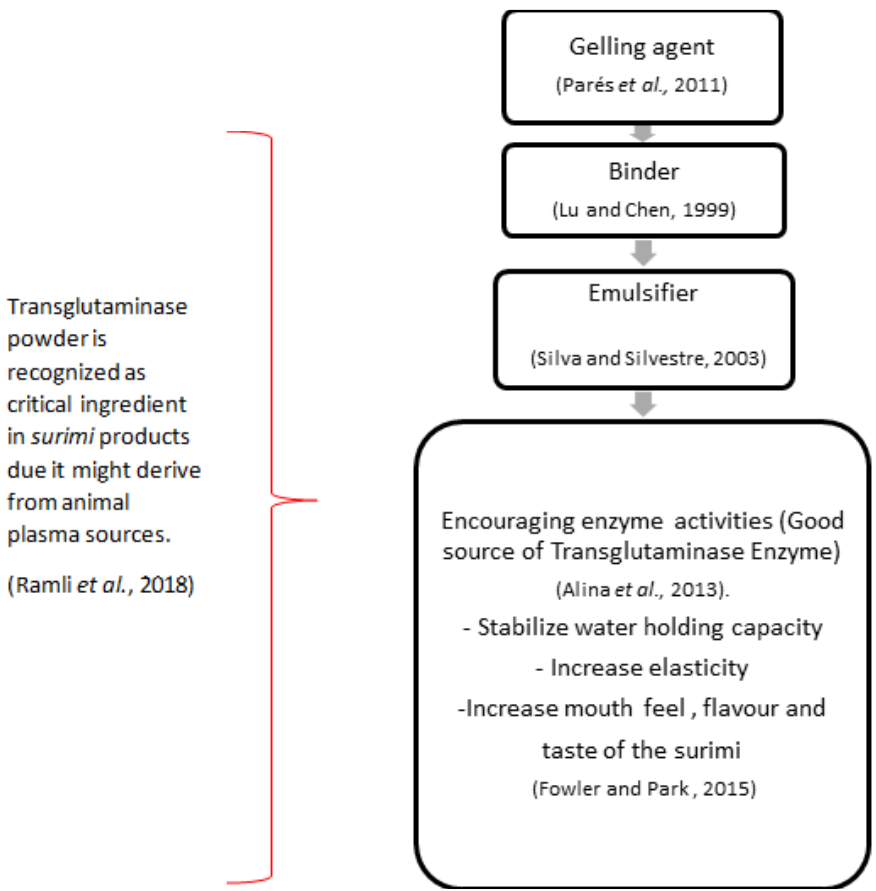

Figure 2. Summary on the functions of animal plasma in surimi products

\section{Conclusion}

In a nutshell, the issue of transforming blood into various food products indicates that more research must be conducted particularly on the utilization of bloodderived products which are a huge concern among religious practitioners such as Muslims, Jews and more. It is undeniable that the rapid development of industrialization processes contributes to economy development because the cost of production can be minimized. The issue of blood transformation signifies science and technology can go beyond the human imagination which requires serious attention from respective authorities, government enforcements and researchers. In addition, consumers are facing difficulties to determine whether the products are permitted to be consumed or otherwise. Due to this concern, consumers are advised to select the food products stamped with the halal logo to confirm the products are totally free from any questionable ingredients. Food producers are also required to use proper labeling on the packaging to maintain the right of consumers to obtain accurate information. Furthermore, Studies should focus on varying scopes related to the issue of blood-derived products to understand current trends, challenges and their potential in future innovations. Therefore, this review paper is intended for researchers, consumers, and policy makers to give them an insight regarding the current trends in the utilization of blood-derived products in the global market.

\section{Conflict of interest}

The authors declared no conflict of interest.

\section{Acknowledgments}

We would like to thank the Malaysia Ministry of Education (MoHE) for financial support via the Fundamental Research Grant Scheme FRGS19-155-0764 to conduct this research. The first author also dedicates special thanks to Yayasan Bank Rakyat for supporting her Master study within two years through scholarship award.

\section{References}

Alao, B.O., Falowo, A.B., Chulayo, A. and Muchenje, V. (2017). The potential of animal by-products in food systems: Production, prospects and challenges. Sustainability (Switzerland), 9(7), 1-18. https:// doi.org/10.3390/su9071089

Alina, A.R., Aqilah, N.A.S., Yusop, M.H.M., Syamsul, K.M.W., Syarifah, N.R.S.A., Mashitoh, A.S. and Kal -Kausar, M.A. (2013). Detection of Blood Transglutaminase Enzyme in Fish Surimi Based Product by Using Polymerase Chain Reaction (PCR) Method. Middle-East Journal of Scientific Research, 13, 29-35. https://doi.org/10.5829/ idosi.mejsr.2013.16.s.10026

Andago, A., Imungi, J., Mwangi, A., Lamuka, P. and Nduati, R. (2015). Development of a Bovine Blood Enriched Porridge Flour for Alleviation of Anaemia among Young Children in Kenya. Food Science and Quality Management, 39(1), 73-84. Retrieved from www.iiste.org

Anuar, R.A. (2015). Ramuan Kritikal Dalam Produk Surimi. Retrieved June 10, 2020 from http:// www.myhealth.gov.my/ramuan-kritikal-dalamproduk-surimi/ [In Bahasa Malaysia].

Aravindran, S., Sahilah, A.M. and Aminah, A. (2014). Market surveillance on non-halal additives incorporated in surimi based products using polymerase chain reaction (PCR)-southern hybridization analysis. AIP Conference Proceedings, 21(6), 2095-2099. https://doi.org/10.1063/1.4895196

Ashwini, A. (2009). Effect of hydrocolloids and emulsifiers on the rheological, microstructural and quality characteristics of eggless cake. Food Hydrocolloids, 23(3), 700-707. https:// doi.org/10.1016/j.foodhyd.2008.06.002

Bah, C.S., Bekhit, A.E.D.A., Carne, A. and Mcconnell, M.A. (2016). Composition and biological activities of slaughterhouse blood from red deer, sheep, pig and cattle. Journal of the Science of Food and Agriculture, 96(1), 79-89. https://doi.org/10.1002/ jsfa. 7062

Barton, M.D. (2000). Antibiotic use in animal feed and its impact on human health. Nutrition Research Reviews, 13(2), 279-299. https:// doi.org/10.1079/095442200108729106 
Bates, R.P., Wu, L.C. and Murphy, B. (1974). Use of animal blood and cheese whey in bread: nutritive value and acceptance. Journal of Food Science, 39 (3), 585-587. https://doi.org/10.1111/j.13652621.1974.tb02954.x

Birla, R., Virk, K., S., Sandhu, H.S., Mehta, N., Kumar, P. and Wagh, R.V. (2018). Safe Disposal of Slaughter House Wastes. Approaches in Poultry, Dairy and Veterinary Sciences, 2(4), 171-173. https://doi.org/10.31031/apdv.2018.02.000542

Boxman, I.L.A., Jansen, C.C.C., Hägele, G., ZwartkruisNahuis, A., Cremer, J., Vennema, H. and Tijsma, A.S.L. (2017). Porcine blood used as ingredient in meat productions may serve as a vehicle for hepatitis E virus transmission. International Journal of Food Microbiology, 257, 225-231. https:// doi.org/10.1016/j.ijfoodmicro.2017.06.029

Colmenero, F.J. (1996). Technologies for developing low-fat meat products. Trends in Food Science and Technology, 7(2), 41-48. https:// doi.org/10.1016/0924-2244(96)81327-6

Duarte, R.T., Carvalho Simões, M.C. and Sgarbieri, V.C. (1999). Bovine blood components: Fractionation, composition, and nutritive value. Journal of Agricultural and Food Chemistry, 47(1), 231-236. https://doi.org/10.1021/jf9806255

Esa, M.S., Huda-Faujan, N., Rajab, H.A. and Rehan, M.M. (2018). Comparison of DNA Concentration and Purity of Animal Blood Extracted Using Different DNA Extraction Kits. Malaysian Journal of Science, Health and Technology, 2(Special Issue), 4-6.

Fowler, M.R. and Park, J.W. (2015). Salmon blood plasma: Effective inhibitor of protease-laden Pacific whiting surimi and salmon mince. Food Chemistry, 176, 448-454. https://doi.org/10.1016/ j.foodchem.2014.12.093

Franke-Whittle, I.H. and Insam, H. (2013). Treatment alternatives of slaughterhouse wastes, and their effect on the inactivation of different pathogens: A review. Critical Reviews in Microbiology, 39(2012), 139-151.

https:// doi.org/10.3109/1040841X.2012.694410

Gandhi, M.S. (2017). What happens to animal blood in slaughterhouses? New Delhi Times, p. 1-12. Retrieved March 21, 2020 from https:// www.newdelhitimes.com/what-happens-to-animalblood-in-slaughterhouses 123/

Griggs, D., Smith, M.S., Rockström, J., Öhman, M.C., Gaffney, O., Glaser, G., Kanie, N., Noble, I., Steffen, W. and Shyamsundar, P. (2014). An Integrated Framework for Sustainable Development Goals. Ecology and Society, 19, 49. https://doi.org/10.5751/ ES-07082-190449
Jabatan Perikanan Malaysia (2015). Surimi. Retrieved January 8, 2020, from Jabatan Perikanan Malaysia website: https://www.dof.gov.my/index.php/pages/ view/144

Jin, S.K., Hur, I.C., Jeong, J.Y., Choi, Y.J., Choi, B.D., Kim, B.G. and Hur, S.J. (2011). The Development of Imitation Crab Sticks by Substituting Spent Laying Hen Meat for Alaska Pollack. Poultry Science, 90 (8), 1799-1808. https://doi.org/10.3382/ps.201001303.

Kashim, M.I.A., Samsudin, M.A. and Mujani, W.K. (2015). International Journal of Social Policy and Society (IJSPS). International Journal of Social Policy and Society, 1, 83-99.

Kok, N., Thawornchinsombut, S. and Park, J.W. (2013). Manufacture of Fish Balls. In Park, J.W. (Ed.) Surimi and Surimi Seafood, p. 285-299. USA: CRC Press https://doi.org/10.1201/b16009-14

Lu, G.H. and Chen, T.C. (1999). Application of egg white and plasma powders as muscle food binding agents. Journal of Food Engineering, 42(3), 147151. https://doi.org/10.1016/S0260-8774(99)00112-0 Lynch, S.A., Mullen, A.M., Neill, E.E.O. and Carlos, A. (2017). Harnessing the Potential of Blood Proteins as Functional Ingredients: A Review of the State of the Art in Blood Processing. Comprehensive Reviews in Food Science and Food Safety, 16(2), 330-344. https://doi.org/10.1111/1541-4337.12254

Mahaiyadin, M.H., Ishak, A.H. and Mohd Yusof, M.F. (2019). Rekonstruksi Hierarki Penggunaan Muharramat Dalam Makanan Ketika Darurah. Jurnal Islam Dan Masyarakat Kontemporari, 20(1), 239-53. [In Bahasa Malaysia].

Mansfield, B. (2003). Fish, factory trawlers and imitation crab: The nature of quality in the seafood industry. Journal of Rural Studies, 19(1), 9-21. https:// doi.org/10.1016/S0743-0167(02)00036-0

Martín-Sánchez, A.M., Navarro, C., Pérez-Álvarez, J.A. and Kuri, V. (2009). Alternatives for efficient and sustainable production of surimi: A review. Comprehensive Reviews in Food Science and Food Safety, 8(4), 359-374. https://doi.org/10.1111/j.1541 $-4337.2009 .00087 . \mathrm{x}$

Meeker, D. and Hamilton, C.R. (2006). An overview of the rendering industry. In Meeker, D.L. (Ed). Essential Rendering: All about the animal byproducts industry. Arlington, VA: National Renderers Association.

Mela, J. (1990). The basis of dietary fat preference. Trends in Food Science and Technology, 1, 71-73. https://doi.org/10.1016/0924-2244(90)90050-9

Ministry of Agriculture Malaysia (2010). Analisa pasaran industri produk berasaskan surimi bagi tempoh 2003 -2010. (2010). Retrieved January 20, 
2020, from Ministry of Agriculture Malaysia website: https://www.moa.gov.my/ documents/20182/70959/surami+pdf.pdf/d8e9246a4c5f-4564-88c1-ec720ab9188b

Mohd Izhar Ariff, M.K., Nur Asmadayana, H., Rifafizah, O., Mohammad Zaini, Y., Rozida, K., Muhammad Adib, S. and Diani Mardiana, M.Z. (2017). Plasma Darah Dalam Makanan Daripada Perspektif Islam Dan Sains. Sains Malaysiana, 46(10), 1779-87. https://doi.org/10.17576/jsm-2017-4610-15 [In Bahasa Malaysia].

Ofori, J.A. (2006). A Sandwich ELISA for Detecting Bovine Blood in Ground Beef and Animal Feed. Florida, USA: Florida State University, MSc. Thesis.

Ofori, J.A. and Hsieh, Y.P. (2011). Blood-derived products for human consumption. Revelation and Science, 1, 14-21.

Ofori, J.A. and Hsieh, Y.P. (2012). The Use of Blood and Derived Products as Food Additives. In Y. ElSamragy (Ed.). Food Additives. InTech Open EBook.

Ofori, J.A. and Hsieh, Y.-H. (2017). Immunodetection of Porcine Red Blood Cell Containing Food Ingredients Using a Porcine-Hemoglobin-Specific Monoclonal Antibody. Foods, 6(11), 101. https:// doi.org/10.3390/foods6110101

Ofori, J.A. and Hsieh, Y.P. (2015). Issues Related to the Use of Blood in Food and Animal Feed Critical Reviews in Food Science and Nutrition Issues Related to the Use of Blood in Food and Animal Feed. Revelation and Science, 54(5), 687-697. https://doi.org/10.1080/10408398.2011.605229

Pangsorn, S., Laong-manee, P. and Siriraksophon, S. (2007). Status of Surimi Industry in the Southeast Asia. Phrasamut-Chedi, Samutprakan, Thailand: Southeast Asian Fisheries Development Center.

Parés, D., Saguer, E. and Carretero, C. (2011). 9 - Blood by-products as ingredients in processed meat. In Kerry, J.P. and Kerry, J.F. (Ed.) Processed meats: Improving safety, nutrition and quality, p. 218-242. USA: Woodhead Publishing Limited. https:// doi.org/10.1533/9780857092946.2.218

Pigott, G.M. (2009). Surimi: The 'High Tech' Raw Materials from Minced Fish Flesh. Food Reviewers International, 2(2), 37-41. https:// doi.org/10.1080/87559128609540796

QL Foods Sdn. Bhd. (2014). Retrieved February 2, 2020, from QL Foods Sdn Bhd website: http:// www.qlfoods.com/

Quality Meat Scotland. (2009). Adding Value to the Scottish Red Meat Supply Chain. Retrieved March 22, 2020 from https://www.qmscotland.co.uk/sites/ default/files/

Final+Project + Report + low + res +8 Jul.pdf
Rahman, A.A. and Abdul, M. (2017). Establishment of Traceability Practices through Halal Assurance System (HAS) Implementation. International Journal of Academic Research in Business and Social Sciences, 7(6), 130-39. https:// doi.org/10.6007/IJARBSS/v7-i6/2951

Ramírez, J.A., Diaz-Sobac, R., Moralez, O.G. and Vázquez, M. (1999). Evaluation of freeze-dried surimi from tilapia and fat sleeper as emulsifiers. Ciência e Tecnologia de Alimentos, 2(4), 210-214. https://doi.org/10.1080/11358129909487604

Ramli, M.A., Salahudin, A., Imran, M. and Razak, A. (2018). Halal Meat Fraud and Safety Issues in Malaysian and Indonesian Market Basic Guidance on Halal Meat. Journal Halal Industry Services, 1 (1), a0000008.

Rawdkuen, S. and Benjakul, S. (2004). Chicken plasma protein: Proteinase inhibitory activity and its effect on surimi gel properties. Food Research International, 37(2), 156-165. https:// doi.org/10.1016/j.foodres.2003.09.014

Sahilah, A.M., Liyana, L.M.N.A.S., Aminah, A. and Mohd Khan, A. (2016). Halal authentication in Malaysia context: potential adulteration of nonHalal ingredients in meatballs and surimi products. International Food Research Journal, 23(5), 18321838.

Santana, P., Huda, N. and Yang, T. (2012). Technology for production of surimi powder and potential of applications. International Food Research Journal, 19(4), 1313-1323.

Satam, S.B. and Yusufzai, S.K.I. (2002). Trends in Production of Surimi and Surimi-based Seafoods. Fishing Chimes, 22(8), 3-10.

Silva, V.D.M. and Silvestre, M.P.C. (2003). Functional properties of bovine blood plasma intended for use as a functional ingredient in human food. $L W T$ Food Science and Technology, 36(7), 709-718. https://doi.org/10.1016/S0023-6438(03)00092-6

Siriraksophon, S., Pangsorn, S. and Laong-manee, P. (2009). The Surimi Industry in Southeast Asia: Trend and Demand for Raw Materials, p. 2-8. Retrieved from Southeast Asian Fisheries Development Center website: http:// repository.seafdec.org/bitstream/ handle/20.500.12066/790/sp7-2\%20surimi\% 20industry.pdf?sequence $=1$

Suhana, I. and Omar, C. (2019). Menggilap usahawan kreatif, inovatif 6. Retrieved June 10, 2020 from https://www.smeinfo.com.my/my/mengenai-kamimobile/berita/item/147-menggilap-usahawan-kreatif, -inovatif. [In Bahasa Malaysia].

Sun, X.D. and Holley, R.A. (2011). Factors influencing gel formation by myofibrillar protein in muscle 
foods. Comprehensive Reviews in Food Science and Food Safety, 10(1), 33-51. https://doi.org/10.1111/ j.1541-4337.2010.00137.x

Tian, N., Nurul, H. and Ruzita, A. (2010). Review Article Surimi-like material: challenges and prospects. International Food Research Journal, 17, 509-517.

Vidal-giraud, B. and Chateau, D. (2007). Globefish Research Programme, Vol. 89. Rome: Food and Agriculture Organization of the United Nations.

Wahab, A.G. (2017). Malaysia Exporter Guide Annual 2017. Retrieved from https://apps.fas.usda.gov/ newgainapi/api/report/downloadreportbyfilename?

filename=Exporter Guide_Kuala Lumpur_Malaysia_11-20-2017.pdf

Walter, T., Hertrampf, E., Pizarro, F., Olivares, M., Llaguno, S., Letelier, A., Vega, V. and Stekel, A. (1993). Effect of bovine-hemoglobin- fortified cookies on iron status of schoolchildren: a nationwide program in Chile. American Journal of Clinical Nutrition, 57(2), 190-194. https://doi.org/10.1093/ajen/57.2.190

Yang, J.H. and Lin, C.W. (1998). Functional properties of porcine blood globin decolourized by different methods. International Journal of Food Science and Technology, 33(4), 419-427. https://doi.org/10.1046/ j.1365-2621.1998.00223.x

Zafar, S. (2019). Biogas from Slaughterhouse Wastes.pdf. Retrieved December 20, 2020, from Bioenergy Consult website: https:// www.bioenergyconsult.com/biogas-fromslaughterhouse-wastes/ 